\title{
CRAF Phase 1, a framework to identify coastal hotspots to storm impacts
}

\author{
Oscar Ferreira ${ }^{1, a}$, Christophe Viavattene ${ }^{2}$, José Jiménez ${ }^{3}$, Annelies Bole ${ }^{4}$, Theocharis Plomaritis ${ }^{1}$, Susana Costas ${ }^{1}$ and \\ Steven Smets ${ }^{4}$ \\ ${ }^{1}$ CIMA-FCT, University of Algarve, Campus de Gambelas, 8005-139, Faro, Portugal \\ ${ }^{2}$ Middlesex University London, Flood Hazard Research Centre, UK \\ ${ }^{3}$ Universitat Politècnica de Catalunya, BarcelonaTech, Spain. \\ ${ }^{4}$ IMDC,Antwerp, Belgium
}

\begin{abstract}
Low-frequency high-impact storms can cause flood and erosion over large coastal areas, which in turn can lead to a significant risk to coastal occupation, producing devastation and immobilising cities and even countries. It is therefore paramount to evaluate risk along the coast at a regional scale through the identification of storm impact hotspots. The Coastal Risk Assessment Framework Phase 1 (CRAF1) is a screening process based on a coastal-index approach that assesses the potential exposure of every kilometre along the coast to previously identified hazards. CRAF1 integrates both hazard (e.g. overwash, erosion) and exposure indicators to create a final Coastal Index (CI). The application of CRAF1 at two contrasting case studies (Ria Formosa, Portugal and the Belgian coast), validated against existing information, demonstrates the utility and reliability of this framework on the identification of hotspots. CRAF1 represents a powerful and useful instrument for coastal managers and/or end-users to identify and rank potential hotspot areas in order to define priorities and support disaster reduction plans.
\end{abstract}

\section{Introduction}

Recent and historic low-frequency, high-impact events such as Xynthia (France in 2010), Hercules (western coast of Europe in 2014), or the 1953 North Sea storm surge (Netherlands, Belgium and the UK), have demonstrated the exposure of coastal areas in Europe to flood and erosion induced risks. Typhoons in Asia (such as Typhoon Haiyan in the Philippines in 2013), hurricanes in the Caribbean and Gulf of Mexico, and Superstorm Sandy, impacting the north-eastern U.S.A. in 2012, have confirmed how coastal flooding events pose a significant risk worldwide and can impact large cities, regions and even countries. Whereas for certain coasts the regional risk is clearly recognized, assessed and managed, for other coasts less attention has been given resulting in a lack of tools and data to perform a coastal risk assessment. Risk assessment also often underestimates the induced losses [1]. Yet, the application of a suite of complex models at a full and detailed regional scale remains difficult to most coastal managers and may not be time and cost efficient or even feasible. Instead, a simplified approach based on simple models and on a screening process to identify and rank hotspots may be a useful and accessible instrument for most coastal managers. Risk assessment can, at a first instance, be performed by simple methods. Those should include simple hazard modelling/formulations and available datasets. Potential losses can also be estimated by using proxies towards the elements exposed to the

\footnotetext{
a Corresponding author: oferreir@ualg.pt
}

hazards. To perform such risk assessment it is required to develop a framework that allows the identification of areas prone to coastal hazards and to rank the potential risk along a coastal region. This, in turn, will permit coastal managers to better allocate resources to prevent or minimise the risk.

This work presents the Coastal Risk Assessment Framework - Phase 1 (CRAF1) that aims to identify hotspots caused by extreme events at coastal areas within a regional scale of about $100 \mathrm{~km}$ of coastal length, a typical "administrative" scale. CRAF1 identifies hotspots by calculating coastal indexes to different hazards and to the potential associated exposure for every alongshore sector $(\sim 1 \mathrm{~km})$. The application of such framework aims to support coastal managers by providing a selection of ranked hotspots allowing them to take informed decisions on how to define priorities and improve their risk assessment. Here, we will present the application and testing of the CRAF1 focusing in two main hazard types: coastal-flooding and coastal-erosion. Simple parametric models have been selected to quickly assess their magnitude for a large number of events (to obtain reliable probabilistic distributions) and for a large number of positions along the coast (to properly characterize hazards at regional scale).

\section{CRAF1 - The framework}

CRAF1 calculates coastal indices $(C I)$ following an existing and established methodology (the index-based 
method). The methodology combines several indicators into a single index, thereby allowing a rapid comparison of coastal sectors [2-5]. However, the type of indicators considered in the index, the way they are ranked and the formula used to combine these variables may differ between studies as the $C I$ is hazard and site specific. A given coastal area can have as many CIs as existing hazards. Indicators must be developed for each hazard and also for each exposure type.

\subsection{Coastal Index}

In CRAF1 a coastal index is calculated for a uniform hazard pathway per sector of one kilometre along the coast by the square root of the geometric mean of the hazard indicator and the overall exposure indicator (eq. 1). The latter is represented by the geometric mean of all considered exposure indicators (eq. 2).

$$
C I=\llbracket\left(i_{h} * i_{\text {exp }}\right) \rrbracket^{\frac{1}{2}}
$$

$i_{\text {exp }}=\llbracket\left(i_{\text {exp-LU }} * i_{\exp -P O P} * i_{\exp -T S} * i_{\text {exp-UT }} * i_{\exp -B S}\right) \rrbracket^{1 / 5}$

The hazard indicator $\left(i_{h}\right)$ is ranked from 0 to 5 (none, very low, low, medium, high, and very high) with the null value referring to the absence of hazard. The exposure indicator $\left(i_{\text {exp }}\right)$ embraces 5 types of exposure representative of the potential direct and indirect impacts: Land Use $\left(i_{\text {exp-LU}}\right)$, Population $\left(i_{\text {exp-POP }}\right)$, Transport $\left(i_{\text {exp-TS }}\right)$, Critical Infrastructure $\left(i_{\text {exp-UT }}\right)$, and Business $\left(i_{\text {exp-BS }}\right)$. Each is ranked from 1 to 5 (non-existent or very low, low, medium, high, and very high). The overall exposure indicator $\left(i_{\text {exp }}\right)$ is ranked similarly from 1 to 5 .

The coastal index is calculated separately for each different hazard and associated return periods. As such if two hazards and three return periods need to be considered for a case study, six coastal indices are calculated.

\subsection{Hazard Indicator}

For each coastal sector identified hazards are assessed and reclassified into a specific-hazard indicator $\left(i_{h}\right)$. The extent of the exposure has also to be determined.

\subsubsection{Define the extreme event (with a given return period)}

The CRAF aims to identify hotpots along the coast associated with given probabilities. The number of hotspots will vary depending on the considered return period of the hazard, with a higher number of hotspots being associated to higher return periods. It is therefore important to define the most appropriate return period(s) for each coastal area. The selection of probabilities to be considered in the analysis can be based on:

(i) The analysis of common probabilities of exceedance. This is the approach adopted in the EU
Floods Directive, which specifies that flood hazard maps and flood risk maps will identify areas with a medium likelihood of flooding (at least 1 in 100 year event) and extremes or low likelihood events

(ii) Use the relevant return periods for coastal management purposes and to integrate them at the definition of the indexes return period.

In hazard analysis in general and in coastal flooding in particular, two main approaches exist commonly known as the event and response methods [6].

The event approach (or deterministic approach) uses the extreme probability distribution of physical parameters. Once the probability of occurrence of the event is selected, wave height and storm surge are obtained from the corresponding extreme distributions. With this approach, each wave height is associated with just one value of other storm parameters, such as wave period and storm duration, which implies the loss of significant information about the natural variability of the process [7]. Once the event associated to a given probability has been defined, the hazard parameters (to characterize flooding and/or erosion) are calculated and associated with the corresponding probability of occurrence.

The response approach (or probabilistic approach) uses the entire wave and water level time series to establish the hazard parameters of interest, such as runup, total water level, overtopping or eroded volume. A probability distribution of extremes is then fitted to the obtained hazard dataset. The hazard parameter of interest (associated with a given probability) will be calculated from its probability distribution. This method is especially recommendable when storm variables (e.g. wave height and period, water level, storm duration) are poorly correlated or statistically independents. This approach is recommended by the FEMA guidelines for flooding studies [8-9]. Therefore, the response approach should be applied, when possible, to assess the magnitude of hazards at regional scale.

\subsubsection{Select and apply the appropriate method to assess hazard intensities}

Coastal hazards and the corresponding storm-induced processes can be grouped in the following main hazard types: marine flooding and erosion.

Marine flooding groups all hazards related to variations in sea water level involving the temporary inundation of the coast at any degree. The lowest flooding level corresponds to overtopping and overwash, which essentially act on the most external coastal fringe. On the other hand, inundation specifically refers to the flood, for a longer time, of a relatively large portion of the coastal fringe due to increased water levels.

Erosion can include either storm induced retreat or long-term coastal erosion (e.g. by sediment scarcity or sea level rise). In order to assess the intensities and the extent of the hazard, several relatively simple methods can be used. As example, some of them are indicated in Table 1. 


\begin{tabular}{|l|l|l|l|}
\hline Hazard & Methods & Outputs & $\begin{array}{l}\text { Description/ } \\
\text { Application }\end{array}$ \\
\hline Overwash & {$[10-12]$} & $\begin{array}{l}\text { Run-up } \\
\text { level }\end{array}$ & $\begin{array}{l}\text { Formulae/ } \\
\text { Natural } \\
\text { beaches }\end{array}$ \\
\hline $\begin{array}{l}\text { Overwash } \\
\text { extent }\end{array}$ & $\begin{array}{l}\text { Simplified } \\
\text { Donnely [13], } \\
\text { XBeach 1D [14] }\end{array}$ & $\begin{array}{l}\text { Water } \\
\text { depth, } \\
\text { velocity } \\
\text { and/or } \\
\text { extent }\end{array}$ & $\begin{array}{l}\text { Model, } \\
\text { formulae/ } \\
\text { natural } \\
\text { beaches and } \\
\text { barriers }\end{array}$ \\
\hline Overtopping & $\begin{array}{l}{[15], \text { EurOtop }} \\
\text { [16], } \\
\text { NNOvertopping }\end{array}$ & $\begin{array}{l}\text { Runu-up } \\
\text { level } \\
\text { and/or } \\
\text { discharge }\end{array}$ & $\begin{array}{l}\text { Formulae/ } \\
\text { Artificial } \\
\text { slopes }\end{array}$ \\
\hline $\begin{array}{l}\text { Coastal } \\
\text { Inundation }\end{array}$ & $\begin{array}{l}\text { Bathtub } \\
\text { approach, } \\
\text { Simple } \\
\text { model }\end{array}$ & $\begin{array}{l}\text { Flood } \\
\text { depth, } \\
\text { velocity }\end{array}$ & $\begin{array}{l}\text { Level, } \\
\text { volume, } \\
\text { discharge/ } \\
\text { Low-lying } \\
\text { areas }\end{array}$ \\
\hline Erosion & $\begin{array}{l}\text { [17-18], XBeach } \\
\text { 1D [14] }\end{array}$ & $\begin{array}{l}\text { Eroded } \\
\text { volume, } \\
\text { shoreline } \\
\text { retreat } \\
\text { and/or } \\
\text { depth }\end{array}$ & $\begin{array}{l}\text { Model, } \\
\text { Formulae/ } \\
\text { Natural } \\
\text { beaches }\end{array}$ \\
\hline
\end{tabular}

Table 1: Proposed methods for assessing hazard (overwash, overtopping and storm induced erosion) intensities and extent.

\subsubsection{Define the hazard extent and the indicator value}

Some of the methods expressed at Table 1 allow directly assessing the hazard extent and the hazard intensity values; for others it may not be as simple. In those cases assumptions on the hazard extent should be done based on the best available information ranging from local knowledge, historic data or existing maps of potential hazard extent or, in the worst case, as a buffer zone of equal distance along the coastline.

The hazard indicator $\left(i_{h}\right)$ is ranked from 0 (no hazard) to 5 (very high hazard) depending on the range and type of hazard intensities (e.g. water depth, water velocity, shoreline retreat). Since it is a site and hazard dependent ranking, it is down to the user to select the most appropriate and representative classification for his case study.

\subsection{Exposure Indicator}

The exposure indicators $\left(i_{\text {exp }}\right)$ measure the relative exposure for different impact categories (land use, population, transport systems, business settings) within the considered hazard-return period extent. A specific approach is used to assess each indicator.

\subsubsection{Land Use}

The Land Use Exposure Indicator ( $i_{\text {exp- } L U}$, eq. 3) measures the relative exposure of land uses along the coast. Importantly, the indicator does not consider the vulnerability of the different land uses, but only the presence of receptors. In other words it indicates the value at risk but not the potential damages. The indicator reflects two components for each sector: the exposed surface and an associated importance value for each land use. The available land use data defines the quality of the assessment and the land use classes to be valued. The importance value of each class should then be discussed and agreed with the selected stakeholders or derived from existing land use valuation.

$$
i_{\text {exp-LU }}=\sum_{j=0}^{n} S_{j} * V_{j}
$$

Where $n=$ number of land use classes, $S=$ surface in $\mathrm{m}^{2}$, $V=$ importance value ( 0 to 10 ). The final obtained values of $i_{\text {exp-LU }}$ are then converted into a scale of 1 to 5 .

\subsubsection{Population and Social Vulnerability}

The Population Exposure Indicator $\left(i_{\text {exp-POP }}\right)$ measures the relative exposure of different communities along the coast. As such, the indicator expresses the relative vulnerability of different areas to long-term health and financial recovery from an event by considering the socio-economic characteristics of the areas exposed to the hazards, obtained from census data. However, in specific circumstances, the characteristics of the population exposed to the hazard might be different from the average characteristics obtained from the census data, often due to differences in the scale of analysis (coastal zone versus municipality level). It is thus important to review these results and to decide if refinements are necessary.

\subsubsection{Systems (transport, utilities and business)}

The last three indicators (transport, utilities, and business) consider the exposure of receptors for which the impact may ripple outside the hazard extent areas. The valuation (Table 2) is ranked according to the importance value of the receptor within its network (potential indirect impact); the greater value being attributed to assets of national or international importance. To do so, the analysis requires considering the regional system associated with these receptors. As such the regional maps of the transport system (road, railway) and information on the different utility networks (water, electricity) and the main economic sector have to be collected and discussed with the relevant stakeholders. Such interaction is essential to reveal potential important impacts, sometimes simply not considered.

\begin{tabular}{|l|l|l|l|}
\hline Valuation & Rank & Description & $\begin{array}{l}\text { Indirect } \\
\text { impacts }\end{array}$ \\
\hline 1 & $\begin{array}{l}\text { Non- } \\
\text { existent or } \\
\text { very low }\end{array}$ & $\begin{array}{l}\text { No significant } \\
\text { network }\end{array}$ & $\begin{array}{l}\text { Direct impact } \\
\text { but no indirect } \\
\text { impact }\end{array}$ \\
\hline 2 & Low & $\begin{array}{l}\text { Mainly local } \\
\text { and small } \\
\text { network }\end{array}$ & $\begin{array}{l}\text { Local and small } \\
\text { indirect impacts }\end{array}$ \\
\hline 3 & Moderate & $\begin{array}{l}\text { Presence of } \\
\text { network with } \\
\text { local and } \\
\text { regional } \\
\text { importance }\end{array}$ & $\begin{array}{l}\text { Significant } \\
\text { indirect impact } \\
\text { at the local scale } \\
\text { and potential at } \\
\text { the regional } \\
\text { scale but with } \\
\text { minor } \\
\text { disruption }\end{array}$ \\
\hline
\end{tabular}




\begin{tabular}{|l|l|l|l|}
\hline 4 & High & $\begin{array}{l}\text { High density of } \\
\text { multiple } \\
\text { networks of } \\
\text { local } \\
\text { importance or } \\
\text { regional } \\
\text { importance }\end{array}$ & $\begin{array}{l}\text { Significant } \\
\text { indirect impact } \\
\text { at the regional. } \\
\text { Disruption of } \\
\text { multiple } \\
\text { services }\end{array}$ \\
\hline 5 & Very High & $\begin{array}{l}\text { High density } \\
\text { and multiple } \\
\text { networks of } \\
\text { national and } \\
\text { international } \\
\text { importance }\end{array}$ & $\begin{array}{l}\text { Indirect impacts } \\
\text { are beyond the } \\
\text { regional scale - } \\
\text { Disruption } \\
\text { observable at } \\
\text { national and } \\
\text { international } \\
\text { scale }\end{array}$ \\
\hline
\end{tabular}

Table 2: Valuation of the systemic value of networks. the open sea by five barrier islands and two peninsulas spatially distributed to produce a cuspate shoreline that extends over $55 \mathrm{~km}$. The back-barrier area consists mainly of tidal flats, salt marshes, small sandy islands, and tidal channels. This site is internationally recognized and protected within the Wetlands of International Importance (Ramsar) Convention and the Birds and Habitats Directive (Natura 2000 Network). At a national level, Ria Formosa was integrated within the Natural Park network of Portugal since 1987. A large part of Ria Formosa has maintained its natural state since then. The beach and dune systems occupy $13 \%$ of the total system among which more than $6 \%$ are grey dunes, a high priority habitat type. The number of residents inhabiting the Ria Formosa drainage basin increased by $\sim 60 \%$
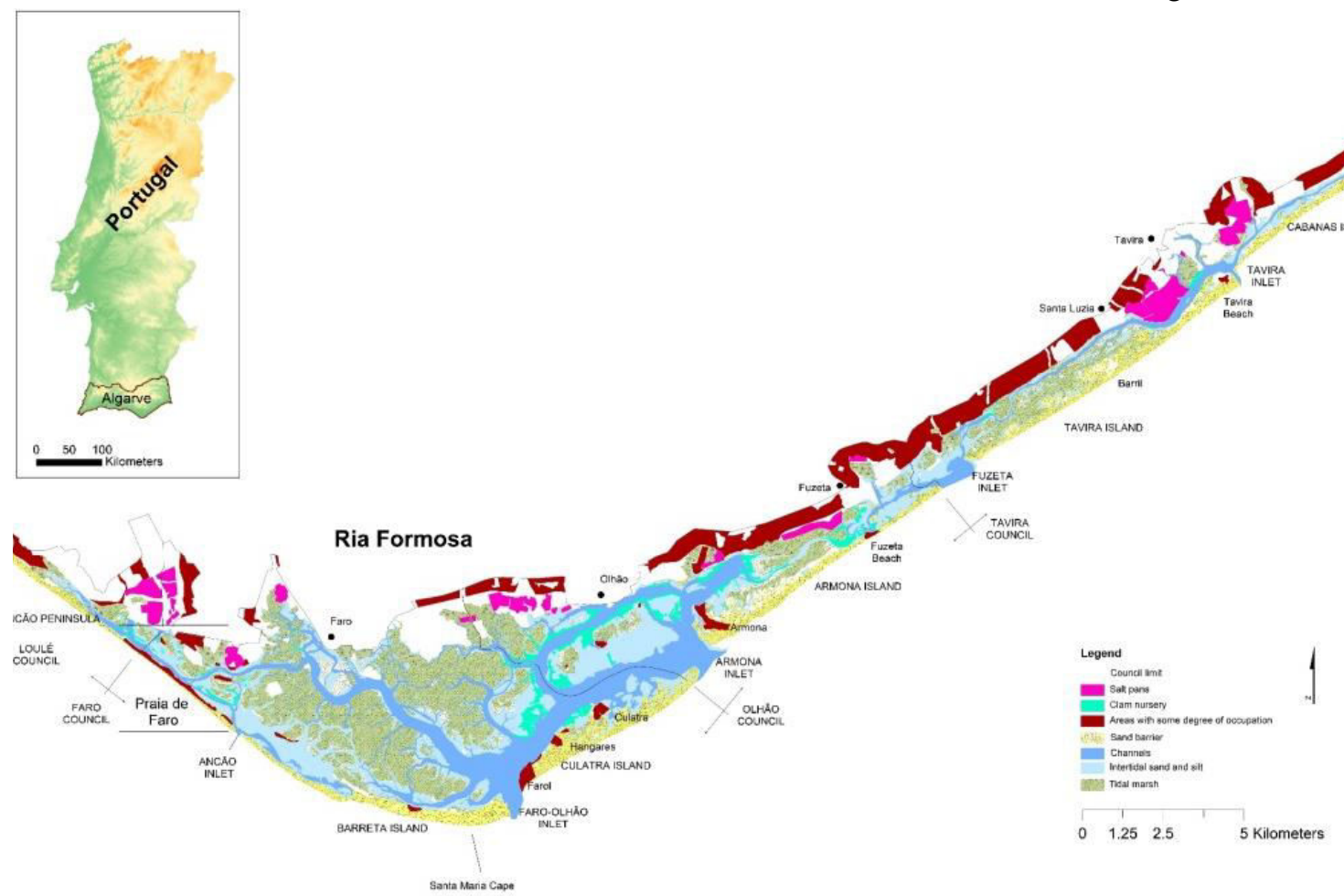

Figure 1: Location and land use map of Ria Formosa (data source: Ria Formosa Natural Park).

\section{Case Studies}

The above described framework was tested at two case studies where the main hotspots and risks are known and identified, the Ria Formosa coastal lagoon at the Algarve (South Portugal) and the entire Belgian coast. The main interest of such application was to validate the framework and check if final results coincide with already known coastal risk hotspots. Only after validation such method can be applied to coastal areas with less knowledge of coastal risks or even with poor available data.

\subsection{Ria Formosa (Algarve, Portugal) - Storm induced retreat}

The Ria Formosa coastal lagoon is situated at the southernmost end of the Portuguese coast (Figure 1). It consists of a lagoon protected from the direct action of between 1970 and 2001. Urban development in Ria Formosa is relatively low and occupies a very small area of the system, concentrated mainly in 5 small villages, most of them located at the back-barrier. However, Praia de Faro and Farol expanded seaward of the frontal dune facing the direct effect of storms.

The Ria Formosa coast was subdivided into 59 sectors of approximately $1 \mathrm{~km}$. Using a topo-bathymetic Lidar DTM of 2011 with $2 \mathrm{~m}$ horizontal resolution, a "worst case scenario" profile was selected as representative of each $1 \mathrm{~km}$ sector. This profile refers to the weakest (smaller dune/berm) point of each sector $(\sim 50 \mathrm{~m}$ alongshore extension).

\subsubsection{Hazard Indicator}

To assess the magnitude of storm-induced erosion hazards the convolution method [17] was used. The 
method has been previously applied and validated for Ria Formosa [19]. The basis for the convolution method is the observation that beach response to steady-state forcing conditions is approximately exponential in time. The duration of the storm and the surge plays an important role in the beach response and controls if the beach will reach a steady-state or not. In the present case study, the retreat for a beach profile with a dune and berm was estimated.

The response approach was followed to determine the extreme event and a wave time series of 20 years was used to extract storm events. In order to obtain independent events of storm conditions a peak over threshold analysis (POT) was used. The threshold value for the POT analysis was set to $2.5 \mathrm{~m}$ wave height and a storm independence criteria (time between two consecutive independent storms) was set to 72 hours (typical length of a synoptic event). Based on the above, a total number of 164 events were found and the characteristic values of wave heights, wave peak period, wave direction and storm duration were obtained for each event. In addition, the associated storm surge for each storm was calculated following an equation derived for the study area [20]. The retreat was computed for every storm and for all sectors, independently. An analysis of extreme values was performed afterwards, per sectors, in order to determine the retreat values associated to different return periods. The General Pareto Distribution was fitted to the data and the values associated to a return period of 50 years (a commonly used return period for coastal management in Portugal) were obtained.

The hazard extent was assumed to be represented by the first line of erosion. The latter is defined here by an area that extends $20 \mathrm{~m}$ inland from the dune foot line. This value was chosen on the basis of the maximum values of storm induced retreat obtained for the entire Ria Formosa. The obtained retreat values ranged from $0 \mathrm{~m}$ (at wider beaches) to almost $25 \mathrm{~m}$ of dune retreat. Retreat classes have been distributed accordingly and results are shown at Figure 2.

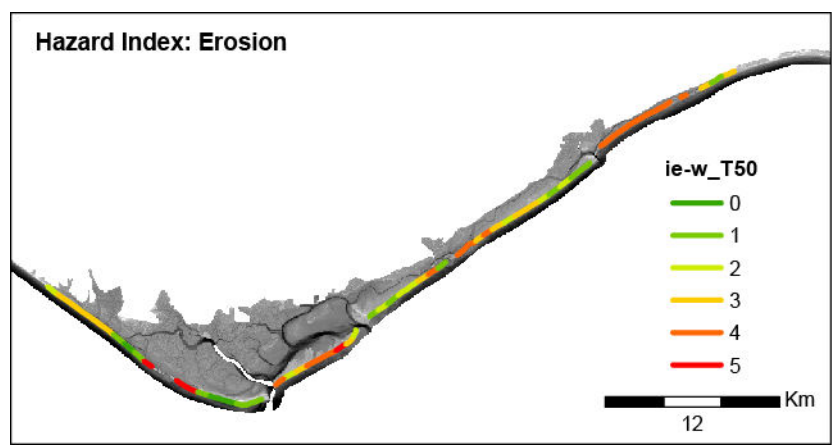

Figure 2. Distribution of the values for the hazard indicator for the 50 year return period and the worst case scenario.

\subsubsection{Exposure Indicator}

The exposure indexes were estimated for each $1 \mathrm{~km}$ sector using the hazard extent of $20 \mathrm{~m}$ from the base of the dune.

Data used to characterize the land use were provided by the Natural Park of Ria Formosa (Figure 1). The provided information shows the spatial distribution of small settlements and vegetation units in the Ria Formosa. From this map, the relevant units or uses were selected and an importance value attributed giving higher relevance to human occupation (e.g, urban areas, value of 5 ; aquaculture, value of 4 ) and lower to the natural (e.g. dunes, value of 3 ; marsh, value of 2 ; tidal flat, value of 1) occupation, due to their expected resilience to coastal storms.

To compute the population and social vulnerability index a specific social vulnerability indicator was developed (eq. 4) to reflect the actual social characteristics of Ria Formosa. Information from four main characteristics was used: Financial deprivation $(F)$, Age $(D)$, Education $(E)$, and Occupation $(\mathrm{Hkm})$. The latter refers to the type of house occupation, i.e. first or second residence, and is one of the most important characteristics at this site, as a large part of the houses within the barrier island settlements corresponds to second residence houses only occupied during summer or holidays, when storm related hazards are reduced. Data from the 2011 census were used to estimate the variables. After standardizing the variables as $\mathrm{Z}$ scores a social vulnerability indicator $(S V I)$ was calculated as:

$$
\text { SVI kmi }=(F+E+D) * 1 / 3+H k m i
$$

The results of the $S V I$ were later re-classified into a scale that varies between 1 and 5 .

The transport systems and utilities in Ria Formosa are limited to networks of local and regional importance; i.e. the levels represented in the area were classified between 1 and 3 .

Business activities in the Ria Formosa are reduced to the presence of restaurants, bars, hotels, and fishing/aquaculture. Aquaculture is one of the major economic activities in the area and represents the largest producer of seafood, namely clams, at a national level, reason why the highest value (5) was assigned to this economic activity.

\subsubsection{Coastal Index}

The $C I$ value was obtained for each $\mathrm{km}$ sector. Most of the area is characterized by a similar, medium, index (Figure 3). The only area that can be defined as a hotspot is the central area of Praia de Faro, on the west flank of Ria Formosa. The rest of the sectors were characterized by $C I$ values no higher than 3 . The main reason for the low $C I$ values is the limited exposure, with very low exposure indicators since the area is poorly occupied. The highlighted hotspot is one of the few occupied areas of the system exposed to storm erosion. The obtained hotspot corresponds to the sector that suffered more damages in the area in the recent years because of the impact of storms, including the partial destruction of the street and buildings (Figure 4). Because of this problem, the highlighted hotspot has a specific and detailed coastal management plan in order to minimise the risk, including house removal, which was only partially implemented by the authorities. 


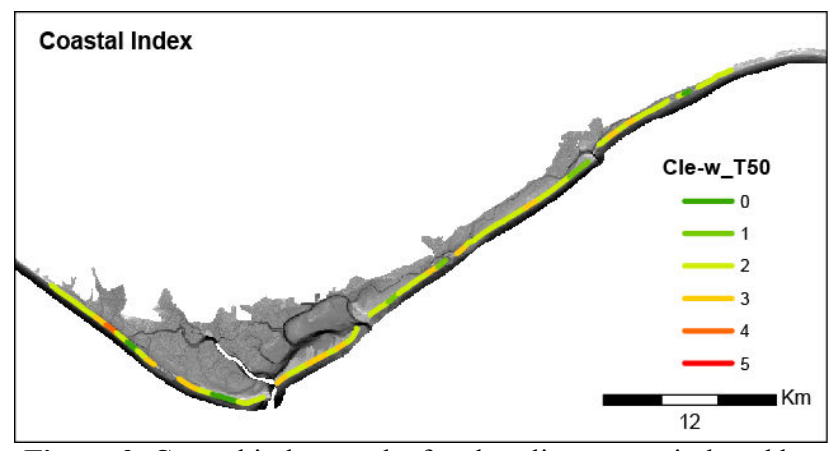

Figure 3. Coastal index results for shoreline retreat induced by storms, with a 50 year return period, at Ria Formosa.

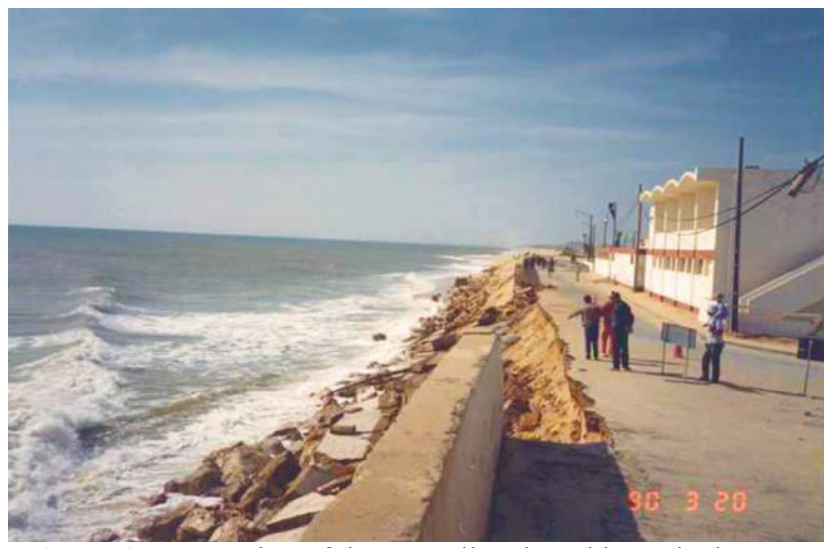

Figure 4. Destruction of the seawall and road in Praia de Faro caused by the impact of storms in 1990 (photo by J.A.Dias).
The hazard considered for the Belgian coast is coastal flooding by overtopping or overflow. For the application of CRAF1, the Belgian coast was subdivided into 26 different sectors, according to:

- the type of the coastal protection: beach + dunes, beach + dike, harbour; and

- the physical characteristics: mainly the crest height of the coastal protection.

The resulting coastal sectors are shown on Figure 5. For each of the ten coastal municipalities, typically 2 profiles were selected. Thus, instead of one profile for each $\mathrm{km}$, an average of one profile every 3 to $4 \mathrm{~km}$ was considered for this case study.

\subsubsection{Hazard Indicator}

Although sufficiently long time series of measured wave conditions and water levels are available, the application of a probabilistic approach would not work to determine the flood hazard in the Belgian case. Using historic time series as input would result in no flooding for the Belgian coast, since the current protection prevents flooding for the conditions of the historic events. To illustrate how highly protected the coast of Belgium is, it must be referred that the protection level around 2010 was already related to a minimum return period of 100 years. This is currently being raised towards a protection level threshold associated to a return period of 1000 years by implementing the measures foreseen in the Masterplan for Coastal Safety, as approved by the

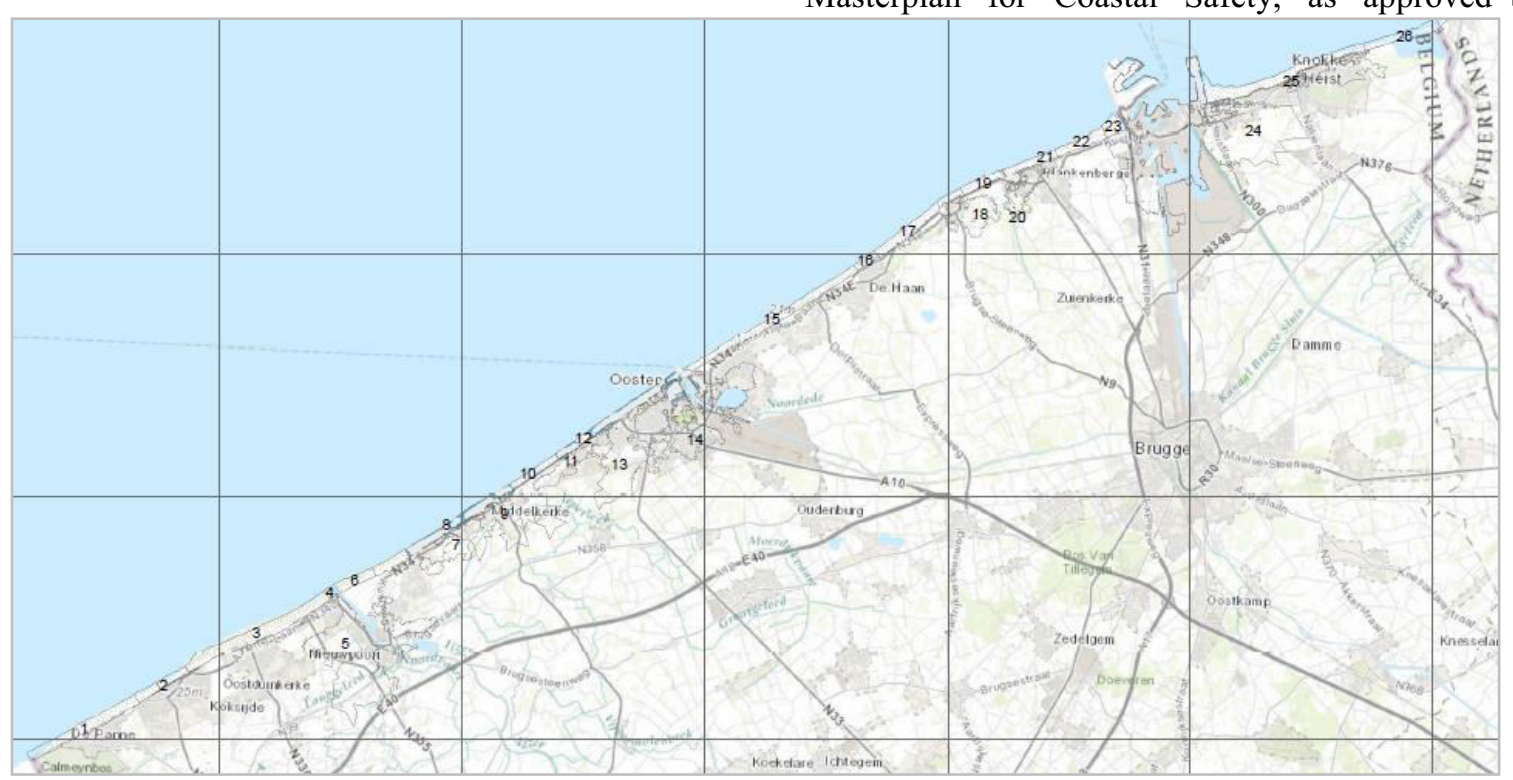

Figure 5: Map of the coastal sectors at the Belgian coast, defined for CRAF1.

\subsection{Belgian coast - Flooding}

The Belgian coast is only $67 \mathrm{~km}$ long, but each metre of this relatively short coastal zone is intensively used. The ten coastal municipalities and cities include not only important seaside resorts, but also two economically important trade harbours, Zeebrugge and Oostende, each of which with industrial areas in the hinterland. Furthermore, four recreational marinas (Nieuwpoort, Oostende, Blankenberge and Zeebrugge) and several valuable nature reserves can be found along the coast.
Flemish government in 2011. For the Belgian case a deterministic approach (event approach) was followed. Extreme value distributions were defined for the hydrodynamic conditions (water levels, wave-heights), so the events can be defined for a number of return periods. The synthetic event here selected has a 4000 year return period (which is above the current management plan), and the configuration of the coastal protection refers to 
the situation before the start of the implementation of the Masterplan for Coastal Safety.

The coastal flooding is caused by the overtopping/overflow of the coastal defences, which consist of beaches, dunes, dikes and port infrastructure in the case of Belgium. For each of the coastal sectors the overtopping or overflow discharge has been calculated with simple 1D models and empirical formulas. For the dune areas no breaching and no discharges have been found. For the ports several profiles have been considered around the port, due to the big variation in structure types and characteristics. These discharges will be the input for determining the hazard extent and the hazard indicator. The extent based on which the exposure indicators are quantified and compared, is defined as the flood extent of each individual coastal sector.

In the case study of Belgium, it turns out to be very difficult or even inappropriate to use the bathtub type approach for delineating the inundation area, as the hinterland is one vast low-lying area. Therefore, a simple 2D model was used to define the exposure zone. A 2D flexible mesh was generated along the whole Belgian coast, with refined mesh near the coast and coarser mesh further inland. The overtopping rate of each coastal sector was inserted as the boundary condition (the overtopping rates of harbours were averaged into one value), and simulated simultaneously to generate the flood extent for each coastal sector.

To generate the hazard index of coastal flooding, the overtopping rates (inflowing volume per running meter) of the return period (T4000) were firstly assembled and normalized between 0 and 1 . Then, the uniformed values were classified into six equal categories, from 0 to 5 . The sections where no overtopping occurs were classified as 0 . The distribution of the obtained hazard index of coastal flooding for the 4000-year return period is shown in Figure 6.

\subsubsection{Exposure Indicator}

To calculate the exposure indicator the inundation area of each coastal sector was firstly classified by types of land uses according to the Corine Land Cover dataset, and then multiplied by their associated value determined by user judgement, summed up and classified from 1 to 5 . Along the Belgian Coast the cities with a dense urbanisation have the highest rank.

The method employed to calculate the population and social vulnerability indicator makes use of existing indicators for Belgium. Three main categories are taken into account: financial deprivation, household structure and age. The data were collected from 2011 census data of Belgium. All the three indicators were calculated and then normalized between 0 and 1 . The final population and social vulnerability index was the sum of the three individual indicators categorised into five equal intervals, from 1 to 5 .

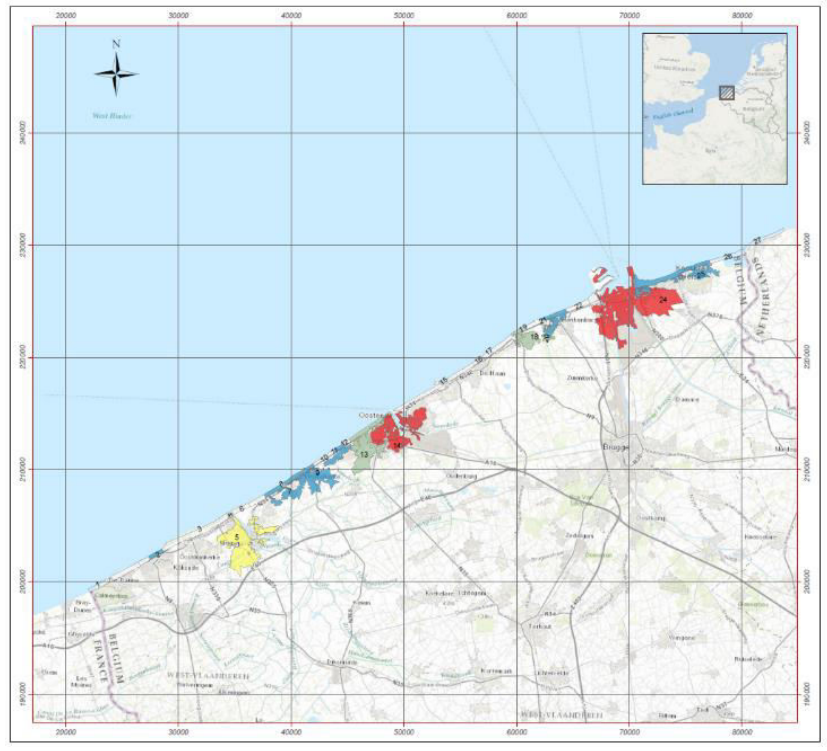

Figure 6: Hazard Index of coastal flooding of 4000-year return period (T4000), along the entire Belgian coast.

The transport system was evaluated based on a qualitative assessment of the affected roads within the exposure area, which were ranked from 1 to 5 . For instance, in Mariakerke, the tramway and road situated on top of the dike are exposed to wave overtopping and flooding.

The utilities were analysed with respect to the supplies of gas, electricity and water. No other data were readily available to assess further utilities. With the available data (from http://www.hoogspanningsnet.com/ and the Flemish Environment Agency, www.vmm.be) four main infrastructures types were analysed for each exposure zone: Liquid Natural Gas terminal, electric transmission network, groundwater extraction zone and water-treatment plant, with values ranking from 1 to 5 depending on the network relevance and density.

A simplified business index was developed, with the number of business sectors (source data: census 2011 Belgium), being used to estimate the index. The number of business sectors per municipality was firstly distributed over the entire urban area to calculate its distribution density, and then multiplied by the total inundated areas to calculate the number of affected business sectors. In the end, the numbers of affected business sectors were summed up per flood exposure zone. The outputs of all coastal sectors were assembled and normalised between 0 and 1 . The normalised indicators were classified into five equal categories, ranking from 1 to 5 .

There are some inherent uncertainties associated with this methodology: firstly, the spatial scale of the raw data is much larger than that of the exposure area, suggesting that the attributes of the business sectors might not represent the exposure area; secondly, one assumption of the method is that the types of business sectors are equally distributed alongshore. 


\subsubsection{Coastal Index}

The final Coastal Index was classified into five equal intervals. The resulting Coastal Index of the Belgian coast for a return period of 4000 years is shown in Figure 7. The used event with return period of 4000 years shows a clear variation of potential impact along the coast, and several potential hotspots, which is logical taking into consideration that the existing protection level along the Belgian coast, before the implementation of the Masterplan for Coastal Safety, was designed for about a 100 years return period. The most vulnerable sites to the coastal flooding are the harbours of Zeebrugge and Ostend (zones 24 and 14, Figure 5), and their respective hinterland areas. The total scores of Zeebrugge and Ostend are very similar. The main difference between the two is that Zeebrugge scores higher in utilities while Ostend scores higher in population and social vulnerability.

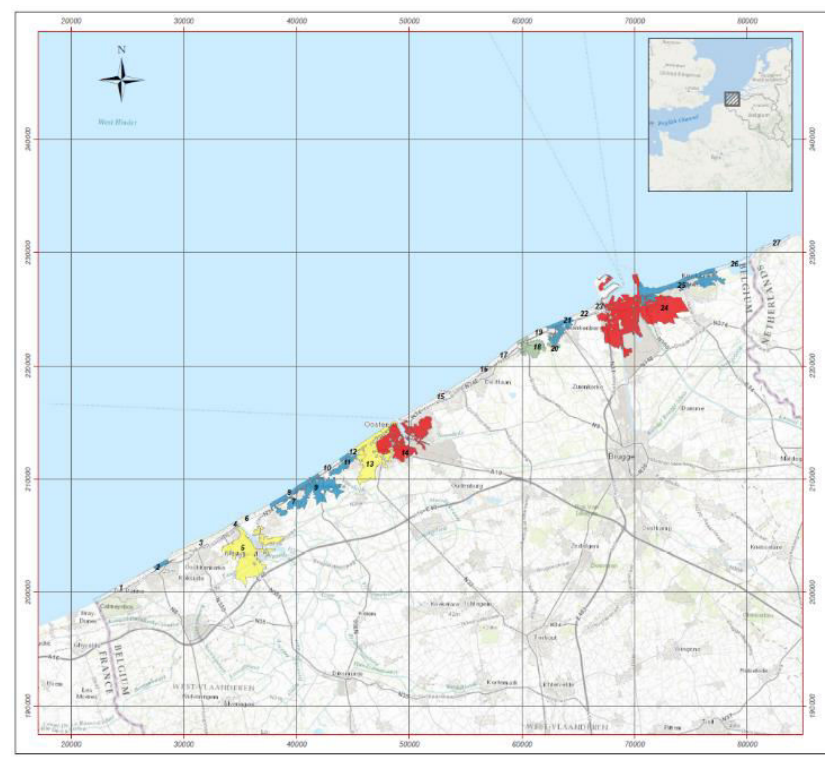

Figure 7: Coastal Index of the Belgian coast for the T4000 flooding.

In order to validate the CRAF1 methodology a comparison was performed against the studies developed at the Masterplan for Coastal Safety, since this case study used the coastal configuration before the implementation of the referred Masterplan. The Belgian Masterplan for Coastal Safety includes a priority list of locations where the safety level should be increased. The first priority level includes the harbours of Oostende and Zeebrugge, both of them being mentioned to have potential flooding problems towards the hinterland. The port of Nieuwpoort (zone 5, Figure 5) and the coastal towns MariakerkeRaversijde (zone 13) also have a high $C I$ value and also figure in the first priority list of the Masterplan. Main differences can be seen in Blankenberge, Middelkerke and de Panne (zones 18, 19 and 2), where the coastal index ranking scores those areas lower, whereas they figure in the priority list of the Masterplan. The Masterplan mainly considers the risk for people, as such focussing on the urbanised areas, and less on industrial areas and economic activities. However, in general, the results of the application of the Coastal Index agree with the already defined priority areas where coastal protection must be improved in Belgium.

\section{Final Remarks}

CRAF1 is a screening but comprehensive method of coastal risk assessment that integrates physical processes, to determine the hazard, and the exposure of the socioeconomic components. This method, although still requiring extended databases and information, is relatively simple and quick to apply over regional scales. It can also deal and incorporate different levels of detail and amount of available data. It permits an assessment of hotspots along large coastal areas, on the order of tens to hundreds of kilometres, by identifying sectors that face potential impacts to a given coastal hazard. The method is developed in a way that can integrate all coastal related hazards (e.g. storm induced erosion, long-term erosion, overwash, inundation, overtopping, breaching, cliff mass movements) as far as the hazard is correctly evaluated, and consider the potential direct and induced losses in the exposure assessment. Furthermore, the methodology is flexible in the selection of the hazard parameterization permitting the selection of the most appropriate formulae by the user, namely by coastal managers.

The adopted approach is also adaptable to the input data characteristics. The hazard index is based on the probabilistic description of the considered hazards, which implies the use of long-term data sets to characterize the forcing and, as a consequence, the induced hazards. In this sense, the tool should be fed by long time series of wave and water level data. However, in cases where instrumental records do not exist and/or they are too short to prevent a reliable extreme analysis, they can be replaced by simulated (hindcast) data (e.g. waves and water levels). The exposure indexes are of general use and rely, for instance, on data from census, but can also include new cartography (if there is no data available), results from questionnaires and local/regional surveys. Therefore, the lack of data can easily be minimised by using complementary information or by creating that information by producing simple maps (e.g. transport network, land use). The method can, therefore, be applied even to areas with some level of data scarcity. Moreover, this framework should be applied with the participation of the end-users (namely coastal managers) that better know the return periods of interest for each area, the existing and more relevant information, and the main hazards to assess. At the end, it will provide them the information to improve coastal management plans towards risk reduction, and will help them to define how to better allocate the existing resources. Furthermore, the time framework of the application can be also included. Once the method is applied, future changes on the socioeconomic data (e.g. land use change or census update), physical (wave, surge) or morphological data (beach profiles) can be incorporated and the $C I$ can be rapidly recalculated. In that sense a time evolution of the $C I$ can be obtained and therefore the evolutionary trends for the 
different hotspots can be evaluated by the coastal managers.

Two contrasting examples of CRAF1 application have been shown in this work. The selected case studies diverge in the type of coast (armoured against natural), in the level of occupation (densely against no occupation) and even in the hazard (flooding against storm erosion). At highly protected coasts, like the Belgian one, the impact of very extreme events can be assessed by using the Coastal Index, in order to distinguish between different potential impacts along the coast and better define future management improvements at selected sites. At areas with a low level of protection (or not protected at all) as it is the case of Ria Formosa, this method allows a first evaluation of hotspots and the identification of areas where risk mitigation is already needed in order to promote risk reduction. The method proved to be robust at both sites, by pointing as coastal hotspots areas where problems already existed or have been identified on existing and future coastal management plans.

The CRAF1 should be followed by the application of a CRAF Phase 2 (currently under development at RiscKit FP7 project: http://www.risckit.eu/) at the selected hotspots, to define in detail (tens to hundred meters) the level of impact of each given hazard and also to perform a complete impact assessment.

\section{Acknowledgments}

This work is a contribution to the EU FP7 research project RISC-KIT-GA-2013-603458 (ResilienceIncreasing Strategies for Coasts - toolKIT). For the Belgian case study the Division Maritime Access of the Flemish government is acknowledged for providing data and for its contribution as end-user. For the Ria Formosa case study the POLIS Ria Formosa and the Natural Park of Ria Formosa are acknowledged for providing data.

\section{References}

[1] Meyer V., Becker N., Markantonis V., Schwarze R., Van den Bergh J. C. J. M., Bouwer L. M., Bubeck P., Ciavola P., Genovese E., Green C., Hallegatte S., Kreibich H., Lequeux Q., Logar I., Papyrakis E., Pfurtscheller C., Poussin J., Przyluski V., Thieken A. H., and Viavattene C. (2013). Assessing the costs of natural hazards - state of the art and knowledge gaps. Natural Hazards Earth System Science, 13, 1351-1373.

[2] Gornitz, V.M. (1990). Vulnerability of the East Coast. Journal of Coastal Research, SI 9, 201-237.

[3] McLaughlin, S., McKenna, J. and Cooper, J.A.G. (2002). Socio-economic data in coastal vulnerability indices: constraints and opportunities. Journal of Coastal Research, SI 36, 487-497.

[4] Ramieri, E., Hartley, A., Barbanti, A., Duarte Santos,F., Gomes, A., Hilden, M., Laihonen, P., Marinova, N. and Santini, M. (2011). Methods for assessing coastal vulnerability to climate change. ETC CCA Technical paper.
[5] Balica, S.F., Wright, N. G., and van der Meulen, F. (2012). A flood vulnerability index for coastal cities and its use in assessing climate change impacts. Natural Hazards, 64, 73-105.

[6] Garrity, N.J., Battalio, R., Hawkes, P.J., and Roupe, D. (2006). Evaluation of the event and response approaches to estimate the 100-year coastal flood for Pacific coast sheltered waters. Proc. 30th ICCE, ASCE, 1651-1663.

[7] Sánchez-Arcilla, A., Jiménez, J.A., and Peña, C. (2009). Wave-induced morphodynamic risks. Characterization of extremes. Coastal Dynamics 2009, World Scientific (CD), paper 127.

[8] Divoky, D. and McDougal, W.G. (2006). Responsebased coastal flood analysis. Proc. 30th Int. Conf. on Coastal Engineering, ASCE, 5291-5301.

[9] FEMA. (2007). Guidelines and Specifications for Flood Hazard Mapping: Atlantic Ocean and Gulf of Mexico coastal guidelines update. Federal Emergency Management Agency.

[10] Holman, R.A. (1986). Extreme value statistics for wave run-up on a natural beach. Coastal Engineering, 9, 527-544.

[11] Nielsen, P., and Hanslow, D.J. (1991). Wave runup distributions on natural beaches. Journal of Coastal Research, 7(4), 1139-1152.

[12] Stockdon, H.F., Holman, R.A., Howd, P.A., and Sallenger, A.H., (2006). Empirical parameterization of setup, swash and run-up. Coastal Engineering, 53, 573-588.

[13] Donnelly, C. (2008). Coastal Overwash: Processes and Modelling. Ph.D. Thesis, University of Lund, p. 53.

[14] Roelvink, D., Reniers, A., van Dongeren, A.P., de Vries, J.V.T., McCall, R., Lescinski, J. (2009). Modelling storm impacts on beaches, dunes and barrier islands. Coastal Eng., 56(11), 1133-1152.

[15] Hedges, T., and Reis, M. (1998). Random wave overtopping of simple seawalls: a new regression model. Water, Maritime and Energy Journal, 1(130), 1-10.

[16] Pullen, T., Allsop, N.W.H., Bruce, T., Kortenhaus, A., Schüttrumpf, H., and van der Meer, J.W. (2007). EurOtop. Wave overtopping of sea defences and related structures: Assessment manual. www.overtopping-manual.com

[17] Kriebel, D. and Dean, R.G. (1993). Convolution model for time-dependent beach-profile response. Journal of Waterway, Port, Coastal and Ocean Engineering, 119, 204-226.

[18] Mendoza, E.T. and Jiménez, J.A. (2006). Storminduced beach erosion potential on the Catalonian coast. Journal of Coastal Research. SI 48, 81-88.

[19] Almeida, L.P., Ferreira, O. and Taborda, R. (2011). Geoprocessing tool to model beach erosion due to storms: application to Faro beach (Portugal). Journal of Coastal Research, SI 64, 1830 - 1834.

[20] Almeida, L.P., Vousdoukas, M.V., Ferreira, O., Rodrigues, B.A. and Matias, A. (2012). Thresholds for storm impacts on an exposed sandy coastal area in southern Portugal. Geomorphology, 143-144, 3 12. 